\title{
DOMINASI GENDER DALAM BUKU BUNGA RAMPAI CERITA RAKYAT TAPANULI TENGAH TERBITAN BALAI BAHASA SUMATERA UTARA
}

\author{
GENDER DOMINATION IN THE ANTOLOGY OF MIDDLE TAPANULI FOLK TALES \\ BOOK PUBLISED BY BALAI BAHASA SUMATERA UTARA
}

\author{
Jamaluddin Nasution \\ FKIP - Universitas Prima Indonesia (UNPRI) \\ djamal.nst@gmail.com
}

Tanggal naskah masuk 26 Maret 2018

Tanggal akhir penyuntingan 6 Juni 2018

\begin{abstract}
The study deals with gender domination featured in characterization for each folktales in the book of Bunga Rampai Cerita Rakyat Tapanuli Tengah (The Anthology of Central Tapanuli Folktales) published by North Sumatera Language Bureau in 2016. This research is used descriptive method by qualitative approach. The data source of this study is 8 (eight) folktales found in the book of Rampai Cerita Rakyat Tapanuli Tengah (The Anthology of Central Tapanuli Folktales), i.e.: (1) Putri Lopian, (2) Putri Runduk, (3) Putri Andam Dewi, (4) Legenda Bukit Batara, (5) Legenda Ujung Sibolga, (6) Legenda Raja dan Burung Dendang Buto, (7) Sonar Paku Bugis, dan (8) Asal Usul Makam Mahligai. From all folktales, there are 10 characters, in which the male characters are 5 (five) and female characters are 5 (five) as well. The result of this study finds that there is no gender domination either male or female in folktales of Central Tapanuli. Male gender featured as a king, a prince, merchant, ship captain, as well as teacher and student who learned Islamic knowledge. Meanwhile, the female gender featured as queen, princess, and the main character's wife. Characterizations and genders are risen because of: (1) the geographical area of Central Tapanuli is in the edge of sea or waters, (2) the governmental system in the past is kingdom, (3) the religion believed is Islam.

Keyword: Gender domination, folktales, Central Tapanuli.
\end{abstract}

Abstrak

Kajian dalam penelitian ini adalah dominasi gender yang muncul dalam penokohan di tiap cerita rakyat yang ada dalam buku Bunga Rampai Cerita Rakyat Tapanuli Tengah (The Anthology of Central Tapanuli Folktales) yang diterbitkan oleh Balai Bahasa Sumatera Utara tahun 2016. Metode yang digunakan dalam penelitian ini adalah metode deskriptif dengan pendekatan kualitatif. Sumber data dalam penelitian ini adalah 8 (delapan) cerita rakyat yang terdapat dalam Buku Rampai Cerita Rakyat Tapanuli Tengah (The Anthology of Central Tapanuli Folktales), yaitu: (1) Putri Lopian, (2) Putri Runduk, (3) Putri Andam Dewi, (4) Legenda Bukit Batara, (5) Legenda Ujung Sibolga, (6) Legenda Raja dan Burung Dendang Buto, (7) Sonar Paku Bugis, dan (8) Asal Usul Makam Mahligai. Dari semua cerita rakyat, terdapat 10 tokoh utama, dimana tokoh laki-laki sebanyak 5 (lima) dan tokoh perempuan juga sebanyak 5 (lima) juga. Hasil dari kajian menemukan bahwa tidak ada dominasi pada salah satu

\begin{tabular}{|l|l|l|l|l|l|}
\hline MEDAN MAKNA & Vol. XVI & No. 1 & HIm. 10 - 19 & Juni 2018 & ISSN 1829-9237 \\
\hline
\end{tabular}


gender dalam cerita rakyat Tapanuli Tengah. Gender laki-laki muncul dalam tokoh seperti raja, pangeran, saudagar, nakhoda, serta guru dan murid yang belajar ilmu Islam. Sementara gender perempuan muncul dalam cerita sebagai tokoh putri raja dan istri tokoh utama. Penokohan dan gender tersebut muncul karena adanya unsur seperti: (1) letak geografi Tapanuli Tengah adalah berada di pinggir laut; (2) sistem pemerintahan masa lalu berbentuk kerajaan; dan (3) faktor agama Islam yang banyak dianut.

Kata kunci: Dominasi gender, cerita rakyat, Tapanuli Tengah

\section{PENDAHULUAN}

Cerita rakyat adalah salah satu karya sastra yaitu berupa cerita yang lahir, hidup dan berkembang pada beberapa generasi dalam masyarakat tradisional, baik masyarakat itu telah mengenal huruf atau belum, disebarkan secara lisan, mengandung survival, bersifat anonim, serta disebarkan di antara kolektif tertentu dalam kurun waktu yang cukup lama. Menurut Suripan (1991) cerita rakyat bisa diartikan sebagai wujud ekspresi suatu budaya yang ada di masyarakat melalui tutur yang mempunyai hubungan secara langsung dengan berbagai aspek budaya serta susunan nilai sosial masyarakat itu sendiri.

Cerita rakyat juga merupakan salah satu bentuk ekspresi budaya daerah yang jumlahnya beratus-ratus di seluruh Indonesia. Bahasa-bahasa daerah yang menjadi media pengucapan tradisi lisan itu juga merupakan bagian dari kebudayaan tradisional, yaitu bahasa yang paling tepat mengekspresikan isi kebudayaan daerah yang bersangkutan (Rosidi, 1995).

Cerita rakyat biasanya hidup atau pernah hidup dalam sebuah masyarakat. Cerita yang ada di dalamnya tersebar, berkembang, atau diturunkan secara lisan dari satu generasi ke generasi yang lebih muda. Cerita rakyat merupakan bagian dari sastra daerah, yakni sastra yang biasanya diungkapkan dalam bahasa daerah. Sebagai contoh, cerita rakyat dari Jawa Tengah, biasanya diceritakan dengan menggunakan bahasa Jawa. Begitu pula cerita rakyat dari Padang, Papua, Batak, dan lainnya yang diceritakan dalam bahasa daerah masingmasing.

Dewasa ini, cerita rakyat telah dikumpulkan dan digunakan dalam dunia pendidikan di Indonesia melalui buku-buku.
Cerita rakyat tidak hanya cerita lisan dari mulut ke mulut tetapi banyak dipublikasikan melalui media.

Di beberapa wilayah Indonesia, cerita rakyat, yang merupakan bagian dari budaya nasional, masih terus dilestraikan seiring usaha pemerintah dalam melestarikan budaya nasional Indonesia itu sendiri. Hal ini sesuai dengan tuntutan UUD NRI 1945 pada pasal 32; (1) Negara memajukan kebudayaan nasional Indonesia di tengah peradaban dunia dengan menjamin kebebasan masyarakat dalam memelihara dan mengembangkan nilai-nilai budayanya, (2) Negara menghormati dan memelihara bahasa daerah sebagai kekayaan budaya nasional.

Salah satu wilayah di nusantara ini yang banyak mengahasilkan cerita rakyat adalah daerah Sumatera Utara. Suku bangsa di Sumatera Utara adalah Batak dengan sub suku seperti Toba, Angkola, Mandailing, dan Karo. Suku lainnya adalah Melayu, Pakpak, Nias, Simalungun, dll. Dan salah satu suku yang memiliki banyak cerita rakyat adalah suku Melayu yang tersebar di wilayah pesisir pantai barat maupun timur pulau Sumatera. Misalnya, suku pesisir di pantai barat Tapanuli Tengah yang kaya akan budaya dan cerita rakyatnya.

Terdapat unsur intrisnsik dan ekstrinsik dalam sebuah karya sastra cerita, semisal cerita rakyat. Unsur Ekstrinsik menurut Nurgiyantoro (2009: 23) adalah unsur yang berada di luar karya fiksi yang mempengaruhi lahirnya karya namun tidak menjadi bagian di dalam karya fiksi itu sendiri. Dan unsur Intrinsik merupakan unsur pembangun karya sastra yang berasal dari dalam karya itu sendiri, seperti tema, plot, penokohan, latar, sudut pandang, gaya bahasa, dan amanat.

\begin{tabular}{|l|l|l|l|l|l|}
\hline MEDAN MAKNA & Vol. XVI & No. 1 & HIm. 10 - 19 & Juni 2018 & ISSN 1829-9237 \\
\hline
\end{tabular}


Penokohan (character) tentu terdiri dari tokoh laki-laki dan perempuan. Banyak cerita rakyat di Indonesia yang menonjolkan penokohan perempuan atau wanita, baik anak kecil maupun dewasa. Cerita-cerita rakyat banyak dengan tokoh utama perempuan, seperti cerita Tangkuban Perahu, Putri Hijau, Nyi Roro Kidul, Malin Kundang, Roro Mendut, dll. Tokoh perempuan muncul sebagai tokoh utama meskipun tokoh laki-laki juga muncul.

Jika mengacu pada studi gender hal ini dapat dipandang sebagai bagian dari institusionalisasi dari domestifikasi perempuan. Karakter wanita yang cantik, lemah, dan lembut adalah kriteria perempuan idaman yang selama ini dikritisi oleh para aktifis gender. Karakter semacam ini dianggap melemahkan wanita dan menempatkan wanita dalam posisi subordinat dan domestik. Hal ini masih diperkuat dengan peran pria dalam berbagai cerita tersebut yang digambarkan kuat, tampan, dan menjadi penyelamat perempuan. Peran pria dengan demikian adalah penyelamat kaum perempuan dan perempuan harus selalu tergantung pada kaum pria.

Berdasarkan perbandingan singkat tersebut maka terlihat bahwa Cerita Rakyat atau folklore disinyalir juga mampu ikut melestarikan dan menginstitusionalisasikan pandangan yang bias gender dalam masyarakat, terutama di Indonesia. Cerita rakyat dengan nilai-nilai yang terkandung di dalamnya memiliki potensi yang besar untuk turut melakukan domestifikasi pada kaum perempuan, mendidik pasar sejak mereka masih anakanak mengenai peran perempuan dalam masyarakat yang subordinat dan selalu berada dibawah laki-laki.

Berdasarkan pendapat tersebut dapat diketahui bahwa cerita rakyat berkembang di masa lalu diwariskan secara lisan. Karena diwariskan secara lisan, seringkali ceritanya mendapat variasi atau tambahan. Hal ini sangat tergantung pada kemahiran yang menceritakan atau pawang cerita. Sehingga cerita yang sama diceritakan dalam versi yang berbeda.

Namun, bagaimana dengan cerita rakyat masyarakat Tapanuli Tengah itu sendiri. Apakah penokohan wanita muncul sebagai karakter yang dominan atau bahkan hanya sebatas penokohan pendukung. Dominasi gender dalam cerita-cerita rakyat tentu akan memunculkan perbedaan nilainilai moral yang disampaikan ataukah hal itu sebuah kebetulan, atau merupakan kekuatan gender yang berbeda di tradisi budaya tersebut.

Dari uraian tersebut, peneliti akan mencoba membahas dominasi gender dalam cerita rakyat masyarakat Tapanuli Tengah yang telah dibukukan dalam buku Bunga Rampai Cerita Rakyat Tapanuli Tengah (The Anthology of Central Tapanuli Folktales) yang diterbitkan oleh Balai Bahasa Sumatera Utara tahun 2016.

Pada penelitian ini, masalah yang diangkat adalah (1) gender apa yang mendominasi dalam cerita rakyat masyarakat Tapanuli Tengah, (2) bagaimana gender itu muncul dalam cerita rakyat masyarakat Tapanuli Tengah, dan (3) kenapa gender tersebut muncul dalam dalam cerita rakyat masyarakat Tapanuli Tengah.

Penelitian ini menjadi penting untuk dilaksanakan karena pemahaman yang baik mengenai dominasi gender dalam cerita rakyat, khususnya cerita rakyat masyarakat Tapanuli Tengah akan menjadi bahan penting bagi setiap orang yang peduli akan permasalahan gender dan akibatnya dalam pembentukan moral masyarakat daerah tersebut, bentuk penghargaan pada gender tertentu, dan pola pikir masyarakat daerah tersebut pada gender. Hasil penelitian ini dapat digunakan untuk memandang cerita rakyat dengan cara yang baru dan menggunakannya secara lebih arif serta bahan referensi penelitian lain yang sejenis dalam menganalisa gender dalam cerita rakyat khususnya cerita rakyat masyarakat Tapanuli Tengah.

Sementara itu, pembatasan masalah dalam penelitian ini dilakukan karena penelitian kualitatif, fenomena yang diteliti 
bersifat partikular. Keterbatasan peneliti secara teknis juga tidak memungkinkan untuk melakukan penelitian dalam cakupan yang lebih luas. Peneliti disini hanya meneliti cerita rakyat yang sudah dikumpulkan dalam buku Bunga Rampai Cerita Rakyat Tapanuli Tengah (The Anthology of Central Tapanuli Folktales) yang diterbitkan oleh Balai Bahasa Sumatera Utara tahun 2016.

\section{METODE}

Desain penelitian ini adalah deskriptif kualitatif. Metode yang digunakan dalam penelitian ini adalah metode deskriptif dengan pendekatan kualitatif. Penelitian deskriptif kualitatif merupakan penelitian yang dimaksudkan untuk memberikan gambaran secara sistematis, faktual dan akurat mengenai data, sifat-sifat serta hubungan fenomena yang diteliti.

Sumber data penelitian ini adalah delapan cerita rakyat masyarakat Tapanuli Tengah yang telah dibukukan dalam buku Bunga Rampai Cerita Rakyat Tapanuli Tengah (The Anthology of Central Tapanuli Folktales) yang diterbitkan oleh Balai Bahasa Sumatera Utara tahun 2016.

Dalam penelitian ini, penulis menggunakan analisis data kualitatif untuk menganalisis data cerita rakyat. Berdasarkan analisis data tersebut, peneliti mengikuti prosedur reduksi data, penyajian data, verifikasi data, dan penyimpulan data.

\section{KAJIAN TEORI \\ Pengertian Cerita Rakyat}

Istilah cerita rakyat menunjuk kepada cerita yang merupakan bagian dari rakyat, yaitu hasil sastra yang termasuk ke dalam cakupan foklor. Cerita rakyat merupakan pernyataan sesuatu budaya kelompok manusia yang mengisahkan berbagai ragam peristiwa yang berkaitan dengan mereka, baik secara langsung atau tidak. Cerita rakyat adalah suatu bentuk karya sastra lisan yang lahir dan berkembang dari masyarakat tradisional yang disebarkan dalam bentuk relatif tetap dan di antara kolektif tertentu dari waktu yang cukup lama dengan menggunakan kata klise (Danandjaja, 2007: 3-4). Pada umumnya, cerita rakyat mengisahkan tentang suatu kejadian di suatu tempat atau asal muasal suatu tempat. Tokoh-tokoh yang dimunculkan dalam cerita rakyat umumnya diwujudkan dalam bentuk binatang, manusia maupun dewa. Cerita rakyat dapat diartikan sebagai ekspresi budaya suatu masyarakat melalui bahasa tutur yang berhubungan langsung dengan berbagai aspek budaya dan susunan nilai sosial masyarakat tersebut.

Cerita rakyat diwariskan secara turun-menurun dari satu generasi ke generasi berikutnya secara lisan. Masyarakat biasanya mewariskan segala yang menyangkut dengan hak milik kelompok dilakukan dengan lisan saja. Jarang sekali masyarakat mewariskan budaya dan tradisi kelompok mereka dengan menggunakan tulisan.

Menurut Danandjaja, (2007:2) cerita rakyat merupakan salah satu bentuk (genre) foklor. Foklor itu sendiri adalah sebagian kebudayaan suatu kolektif yang tersebar dan diwariskan turun-temurun di antara kolektif macam apa saja, secara tradisional dalam versi yang berbeda, baik dalam bentuk lisan maupun contoh yang disertai gerak isyarat atau alat pembantu pengingat (memonic device).

Berdasarkan pendapat tersebut dapat diketahui bahwa cerita rakyat merupakan cakupan foklor yang berkembang di masa lalu dan diwariskan secara lisan. Karena diwariskan secara lisan, seringkali ceritanya mendapat variasi atau tambahan. Hal ini sangat tergantung pada kemahiran pencerita/tukang cerita. Dengan demikian, cerita yang sama bisa saja diceritakan dalam versi yang berbeda.

\section{Kategori Cerita Rakyat}

Kategori yang dimaksudkan pada pembahasan ini adalah golongan atau jenis cerita rakyat. Dalam pembahasan kategori cerita rakyat, Bascom (Danandjaja, 2007:50) membagi cerita prosa rakyat menjadi tiga jenis, yaitu; (1) mite, (2) legenda, dan (3) dongeng. Lain halnya dengan Wundt,

\begin{tabular}{|l|l|l|l|l|l|}
\hline MEDAN MAKNA & Vol. XVI & No. 1 & HIm. 10 - 19 & Juni 2018 & ISSN 1829-9237 \\
\hline
\end{tabular}


mengkategorikan cerita rakyat menjadi tujuh jenis, yaitu: (1) cerita dongeng mitos, (2) cerita pari-pari tulen, (3) cerita-cerita dan dongeng-dongeng tumbuhan, (4) dongeng binatang tulen, (5) cerita asal-usul, (6) ceritacerita dan dongeng-dongeng jenaka, dan (7) dengong-dongeng moral.

Secara garis besar, dapat disimpulkan bahwa kategori cerita rakyat terdiri dari tiga jenis, yaitu (1) mite, (2) legenda, dan (3) dongeng karena sudah mencakup secara keseluruhan dan mudah dipahami.

\section{Fungsi Sosial Cerita Rakyat}

Menurut Semi (1984:10-14) cerita rakyat memiliki empat fungsi sosial, yaitu: (1) Menghibur adalah suatu karya sastra yang diciptakan berdasarkan keinginan melahirkan suatu rangkaian berbahasa yang indah dan bunyi yang merdu saja, (2) mendidik adalah suatu karya sastra yang dapat memberikan pelajaran tentang kehidupan, karena sastra mengekspresikan nilai-nilai kemanusiaan seperti yang terdapat dalam agama. Nilai-nilai yang disampaikannya dapat lebih fleksibel. Di dalam sebuah karya sastra yang baik kita akan menemui unsur-unsur dari ilmu filsafat, ilmu kemasyarakatan, (3) mewariskan adalah suatu karya sastra yang dijadikan alat untuk meneruskan tradisi suatu bangsa dalam arti yang positif. Tradisi itu memerlukan alat untuk meneruskannya kepada masyarakat sezaman dan masyarakat yang akan datang, (4) jati diri adalah suatu karya sastra yang menjadikan dirinya sebagai suatu tempat di mana nilai kemanusiaan mendapat tempat yang sewajarnya, dipertahankan, dan disebarluaskan, terutama di tengah-tengah kehidupan modern yang ditandai dengan menggebu-gebunya kemajuan sains dan teknologi.

Berkaitan dengan hal di atas, Atmazaki (2007:138) mengemukakan bahwa fungsi sosial sastra lisan meliputi: (1) untuk mengekspresikan gejolak jiwa dan renungannya tentang kehidupan oleh masyarakat purba atau nenek moyang kita dahulu, (2) untuk mengukuhkan solidaritas dan menyegarkan pikiran dan perasaan, (3) digunakan untuk memuji raja, pemimpin, dan orang-orang yang diangggap suci, keramat, dan berwibawa oleh kolektifnya. Menurut Bascom fungsi tersebut ada empat: (1) sebagai sistem proyeksi, (2) sebagai alat pengesahan kebudayaan, (3) sebagai alat pedagogik, dan (4) sebagai alat pemaksa berlakunya norma masyarakat dan pengendalian masyarakat.

\section{Gender Dalam Kesusastraan}

Gender sering diidentikkan dengan jenis kelamin (seks), padahal gender berbeda dengan jenis kelamin. Jenis kelamin (seks) mengandung arti alat atau jenis kelamin (jantan atau betina). Laki-laki dan perempuan sebagai makhluk yang secara kodrati memiliki fungsi-fungsi organisme yang berbeda. Perbedaan jenis kelamin mengacu pada perbedaan fisik, terutama fungsi reproduksi, sedangkan gender merupakan interpretasi sosial dan kultural terhadap perbedaan jenis kelamin. Gender membagi atribut pekerjaan menjadi maskulin dan feminin. Biasanya, maskulin ditempati oleh jenis kelamin laki-laki, sedangkan feminin oleh jenis kelamin perempuan. Konsep ini kemudian melahirkan stereotipe perempuan dan laki-laki. Perempuan bersifat lembut, cantik, emosional, dan keibuan, sedangkan laki-laki bersifat kuat, rasional, dan perkasa (Sugihastuti dan Suharto, 2010:64).

Dalam sebagian besar masyarakat di seluruh dunia, laki-laki sering kali dianggap sebagai kaum superior dan perempuan sebagai kaum inferior. "Anak laki-laki, lebih lebih dalam sistem kekeluargaan partiarkhat selalu menjadi satu satunya harapan dalam melanjutkan keturunan." (Ratna: 2007. Lakilaki dianggap figur otoritas sedangkan perempuan dikenal sebagai makhluk lembut, setia, dan penuh pengabdian.

Umumnya suku di Sumatera Utara, peranan laki-laki lebih dominan. Hal ini terlihat dari garis marga yang ditarik dari ayah (patrilineal). Dalam acara adat juga dapat terlihat dominasi laki-laki dalam hal berbicara yang disebut dengan markobar, 
baik dari pihak calon suami / istri (Nasution: 2007)

Untuk mengkaji bagaimana perspektif gender dalam sebuah karya sastra, diperlukan sebuah alat analisis. Kritik Sastra Feminis merupakan salah satu disiplin ilmu Kritik yang lahir sebagai reapons atas berkembangluasnya feminisme di berbagai penjuru dunia (Sugihastuti dan Suharto, 2010:61). Salah satu kajian (kritik) sastra feminis adalah kritik sastra feminis ideologis. Kritik sastra feminis ideologis adalah kritik sastra yang memusatkan pada citra serta stereotipe perempuan dalam karya sastra, meneliti tentang kesalahpahaman tentang perempuan, dan meneliti sebabsebab perempuan sering tidak diperhitungkan, bahkan nyaris diabaikan dalam kritik sastra.

Salah satu konsep dasar yang digunakan di dalam kritik sastra feminis adalah konsep gender. Bainar (1998:11) mengatakan gender adalah identitas gramatikal yang berfungsi mengklasifikasikan suatu benda pada kelompok-kelompoknya. Identitas ini seringkali dirumuskan dengan "feminin" dan "maskulin".

\section{Tapanuli Tengah}

Tapanuli Tengah adalah sebuah kabupaten di Sumatera Utara dan ibu kotanya adalah Pandan. Namun kota Sibolga juga sering dikategorikan sebagai bagian Tapanuli Tengah meskipun secara pemerintahan kota Sibolga adalah kota yang telah dimekarkan.

Tapanuli Tengah adalah kabupaten yang berada di pesisir barat Sumatera Utara. Hampir 50\% Suku Indonesia dan Luar negeri ada di Tapanuli Tengah. Mayoritas penduduknya adalah Suku Batak Toba, Mandailing, dan Melayu.

Kabupaten Tapanuli Tengah terletak di pesisir Pantai Barat Pulau Sumatera dengan panjang garis pantai $200 \mathrm{~km}$ dan wilayahnya sebagian besar berada di daratan pulau Sumatera dan sebagian lainnya di pulau-pulau kecil dengan luas wilayah 2.188 $\mathrm{Km}^{2}$.
Penduduk Tapanuli Tengah tahun 2010 berpenduduk sekitar 311.232 jiwa dengan kepadatan penduduk 136 jiwa per $\mathrm{km}^{2}$. Laju pertumbuhan penduduk periode tahun 2005-2010 sebesar 1,86\% per tahun. Komposisi penduduk di Tapanuli Tengah yaitu 50,20\% laki-laki dan 49,80\% perempuan

(https://id.wikipedia.org/wiki/Kabupaten_Ta panuli_Tengah).

\section{HASIL}

Dari delapan cerita rakyat yang terdapat pada Buku Bunga Rampai Cerita Rakyat Tapanuli Tengah (The Anthology of Central Tapanuli Folktales) terdapat 10 tokoh utama. Dalam cerita rakyat ke-5 berjudul "Legenda Ujung Sibolga" dan cerita rakyat ke-6 dengan judul "Legenda Raja dan Burung Dendang Buto", terdapat dua penokohan utama sehingga total tokoh utama adalah 10. Data tersebut terlihat seperti dalam tabel berikut;

Tabel 1

Cerita rakyat Tapanuli Tengah

\begin{tabular}{|c|c|c|c|}
\hline \multirow[b]{2}{*}{ No } & \multirow[b]{2}{*}{$\begin{array}{l}\text { Judul Cerita } \\
\text { Rakyat }\end{array}$} & \multicolumn{2}{|c|}{ Tokoh Utama } \\
\hline & & $\begin{array}{l}\text { Laki- } \\
\text { laki }\end{array}$ & $\begin{array}{l}\text { Perem } \\
\text { puan }\end{array}$ \\
\hline 1 & Putri Lopian & & $\sqrt{ }$ \\
\hline 2 & Putri Runduk & & $\sqrt{ }$ \\
\hline 3 & $\begin{array}{l}\text { Putri Andam } \\
\text { Dewi }\end{array}$ & & $\sqrt{ }$ \\
\hline 4 & $\begin{array}{l}\text { Legenda Bukit } \\
\text { Batara }\end{array}$ & $\sqrt{ }$ & \\
\hline 5 & $\begin{array}{l}\text { Legenda Ujung } \\
\text { Sibolga }\end{array}$ & $\sqrt{ }$ & $\sqrt{ }$ \\
\hline 6 & $\begin{array}{l}\text { Legenda Raja } \\
\text { dan Burung } \\
\text { Dendang Buto }\end{array}$ & $\sqrt{ }$ & $\sqrt{ }$ \\
\hline 7 & $\begin{array}{l}\text { Sonar Paku } \\
\text { Bugis }\end{array}$ & $\sqrt{ }$ & \\
\hline 8 & $\begin{array}{l}\text { Asal Usul } \\
\text { Makam } \\
\text { Mahligai }\end{array}$ & $\sqrt{ }$ & \\
\hline & Jumlah & 5 & 5 \\
\hline & Persentasi & $50 \%$ & $50 \%$ \\
\hline
\end{tabular}

Cerita rakyat Tapanuli Tengah dalam Buku Bunga Rampai Cerita Rakyat Tapanuli Tengah (The Anthology of Central Tapanuli Folktales) terdiri dari 10 tokoh utama, 
dimana tokoh laki-laki sebanyak 5 (lima) dan tokoh perempuan sebanyak 5 (lima) juga.

Gender tersebut muncul sebagai tokoh utama dengan karakter putri sebanyak 3 tokoh, yaitu: (1) Putri Lopian, (2) Putri Runduk, (3) Putri Andam Dewi, serta dua orang sebagai istri tokoh utama, yaitu; (4) Siti Rudiyah sebagai istri yang setia dalam cerita Legenda Ujung Sibolga, dan (5) istri Raja yang sangat menyayangi anak gadisnya dalam cerita Legenda Raja dan Burung Dendang Buto.

Sementara penokohan laki-laki muncul sebagai; (1) Pangeran Situngkus, (2) Khulifah Alwi sebagai tokoh yang alim, (3) Raja yang kejam dalam cerita Legenda Raja dan Burung Dendang Buto, (4) Tuan Bugis sebagai saudagar, dan (5) seorang murid laki-laki dalam cerita Asal Usul Makam Mahligai.

Penokohan laki-laki dan wanita dalam sebuah cerita bukanlah terjadi dengan maksud tertentu. Namun, kemunculan tokoh tersebut dipengaruhi oleh aspek sosial budaya yang berkembang di daerah tersebut. Seperti daerah Tapanuli Tengah yang merupakan daerah dengan geografi laut sehingga memunculkan cerita rakyat yang erat dengan laut. Daerah laut sebagai media transportasi akan memunculkan tokoh-tokoh seperti saudagar (laki-laki), dan nakhoda (laki-laki).

Bentuk sosial budaya lain adalah bentuk pemerintahan masa lalu yang berbentuk kerajaan, dan sebuah kerajaan pasti memiliki raja (laki-laki), pangeran (laki-laki) dan putri raja (perempuan) serta istri raja / permaisuri (perempuan). Tokohtokoh tersebut merupakan tokoh sentral dan utama dalam sebuah cerita.

Faktor agama Islam juga mempengaruhi cerita rakyat Tapanuli Tengah dalam Buku Bunga Rampai Cerita Rakyat Tapanuli Tengah (The Anthology of Central Tapanuli Folktales). Seperti cerita "Legenda Ujung Sibolga" dengan tokoh utama Khulifah Alwi sebagai orang alim yang mengajar agama Islam dan istrinya yang setia pada suami yaitu Siti Rudiyah. Dalam "Asal Usul Makam Mahligai” juga muncul tokoh murid laki-laki yang baik yang sedang berguru ilmu Islam pada gurunya.

Sehingga dapat disimpulkan kemunculan tokoh baik laki-laki maupun perempuan dalam cerita rakyat Tapanuli Tengah dalam Buku Bunga Rampai Cerita Rakyat Tapanuli Tengah (The Anthology of Central Tapanuli Folktales) yang dikeluarkan oleh Balai Bahasa Sumatera Utara karena unsur: (1) letak geografi Tapanuli Tengah adalah laut; (2) sistem pemerintahan kerajaan; (3) faktor agama Islam.

\section{PEMBAHASAN}

Cerita rakyat adalah cerita yang berkembang disetiap daerah dan menceritakan asal usul atau legenda yang terjadi disuatu daerah; cerita yang berasal dari masyarakat dan berkembang dalam masyarakat. Cerita rakyat merupakan bagian dari dongeng. Ciri-ciri cerita rakyat, yaitu: (1) Cerita rakyat disampaikan secara lisan, (2) disampaikan secara turun-temurun, (3) tidak diketahui siapa pertama kali membuatnya, (4) kaya nilai-nilai luhur, (5) bersifat tradisional, (6) memiliki banyak versi dan variasi, dan (7) mempunyai bentukbentuk klise dalam susunan atau cara pengungkapannya.

Pada cerita rakyat Tapanuli Tengah dalam Buku Bunga Rampai Cerita Rakyat Tapanuli Tengah (The Anthology of Central Tapanuli Folktales), cerita rakyat disampaikan secara lisan dan dibukukan oleh Balai Bahasa Sumatera Utara. Cerita rakyat tersebut diyakini adalah hasil budaya yang turun temurun disampaikan dan tidak diketahui secara pasti siapa yang membuatnya. Setting cerita yang sangat tradisional, seperti cerita kerajaan, misalnya: Putri Lopian, Putri Runduk, Putri Andam Dewi. Legenda juga bersifat tradisional dan memiliki banyak nilai-nilai luhur, seperti: Legenda Bukit Batara, Legenda Ujung Sibolga, dan Legenda Raja dan Burung Dendang Buto.

Setiap karya sastra memiliki unsurunsur pembangun / unsur sastra, begitu pula dengan cerita rakyat. Seperti unsur Instrinsik, unsur instrinsik adalah unsur yang

\begin{tabular}{|l|l|l|l|l|l|}
\hline MEDAN MAKNA & Vol. XVI & No. 1 & HIm. 10 - 19 & Juni 2018 & ISSN 1829-9237 \\
\hline
\end{tabular}


membangun cerita dari dalam. Unsur-unsur instrinsik cerita rakyat adalah tema. Tema merupakan pokok pikiran yang dipakai sebagai dasar pengarang; pokok pikiran pengarang; ide pokok permasalahan. Dari 8 (delapan) cerita rakyat Tapanuli Tengah terlihat tema yang muncul antara lain: (1) Putri Lopian bertema putri yang kehilangan keluarga, (2) Putri Runduk bertema putri cantik yang dipinang oleh raja, (3) Putri Andam Dewi bertema kerajaan yang hancur oleh burung garuda, (4) Legenda Bukit Batara adalah legenda asal usul sebuah bukit yang disebut Bukit Batara, (5) Legenda Ujung Sibolga bertema asal usul kota Sibolga, (6) Legenda Raja dan Burung Dendang Buto bertema seorang raja yang kejam dan ingin membunuh anak perempuannya, (7) Sonar Paku Bugis memiliki tema seorang saudagar dan nakhoda yang ingin mengambil ajimat, dan (8) Asal Usul Makam Mahligai bertema seorang laki-laki yang belajar ilmu agama.

Unsur yang lain adalah alur cerita. Alur adalah jalannya cerita; rangkaian peristiwa yang membentuk cerita dengan dasar hubungan sebab akibat. Pada umumnya alur ada tiga macam, yaitu: (1) alur maju, (2) alur mundur, (3) alur gabungan (gabungan dari alur maju dan alur mundur). Semua cerita rakyat Tapanuli Tengah dalam Buku Bunga Rampai Cerita Rakyat Tapanuli Tengah (The Anthology of Central Tapanuli Folktales) memiliki alur maju.

Latar juga adalah unsur penting dalam cerita. Latar meliputi eterangan tentang tempat, waktu dan suasana; tempat/waktu terjadinya peristiwa. Latar ada tiga macam, yaitu: (1) Latar tempat, semua cerita berlokasi di Tapanuli Tengah. (2) Latar waktu, dimana cerita rakyat dalam Buku Bunga Rampai Cerita Rakyat Tapanuli Tengah (The Anthology of Central Tapanuli Folktales) berlatar waktu masa lalu.

Penokohan adalah lukisan watak pelaku; cara pengarang menggambarkan watak tokoh. Istilah tokoh menunjukkan pada orangnya, pelaku cerita, sedangkan pekonokohan menunjukkan pada sikap kualitas pribadi tokoh.

Dilihat dari fungsi penampilan tokoh dalam cerita, tokoh dibedakan atas dua, yaitu: (1) Protagonist, adalah tokoh yang berfungsi memberikan simpati, empati, melibatkan diri secara emosional terhadap tokoh tersebut. (2) Antagonis, adalah tokoh yang berfungsi menimbulkan konflik dan berposisi dengan tokoh protagonist.

Kedudukan pengarang dalam cerita; cara pandang pengarang disebut dengan sudut pandang. Setiap pengarang memiliki sudut pandang penceritaan yang berbeda. Ada yang menggunakan sudut pandang penceritaan orang pertama (aku atau saya); ada yang menggunakan sudut pandang penceritaan orang kedua (kamu atau kau); dan ada juga yang menggunakan sudut pandang orang ketiga (ia, dia atau nama orang).

Dalam cerita rakyat tapanuli Tengah dalam Buku Bunga Rampai Cerita Rakyat Tapanuli Tengah (The Anthology of Central Tapanuli Folktales) memiliki sudut pandang orang ketiga yaitu nama-nama tokoh seperti putri, raja, nama tokoh, dan lain sebagainya.

Amanat adalah hal-hal yang disampaikan pengarang atau pemberi cerita. Amat yang disampaikan dalam cerita rakyat Tapanuli Tengah adalah pesan moral dari orangtua pada golongan muda melalui media hiburan cerita.

Unsur Ekstrinsik cerita rakyat adalah unsur yang berada di luar karya sastra atau cerita namun turut menetukan bentuk dan isi suatu karya atau cerita. Unsur-unsur eksttrinsik cerita rakyat, yaitu: agama, politik, moral, aliran pengarang, psikologi, sejarah, sosial budaya, dan lain-lain.

Dalam cerita rakyat Tapanuli Tengah yang ada dalam Buku Bunga Rampai Cerita Rakyat Tapanuli Tengah (The Anthology of Central Tapanuli Folktales) terlihat unsur agama Islam seperti cerita "Legenda Ujung Sibolga" dengan tokoh utama Khulifah Alwi sebagai orang alim yang mengajar agama Islam dan istrinya yang setia pada suami yaitu Siti Rudiyah. Dalam "Asal Usul Makam Mahligai" juga muncul tokoh murid

\begin{tabular}{|l|l|l|l|l|l|}
\hline MEDAN MAKNA & Vol. XVI & No. 1 & HIm. 10 - 19 & Juni 2018 & ISSN 1829-9237 \\
\hline
\end{tabular}


laki-laki yang baik yang sedang berguru ilmu Islam pada gurunya.

Bentuk sosial budaya juga terlihat seperti bentuk pemerintahan masa lalu yang berbentuk kerajaan, dan sebuah kerajaan pasti memiliki raja (laki-laki), pangeran (laki-laki) dan putri raja (perempuan) serta istri raja / permaisuri (perempuan).

Dari semua unsur-unsur di atas memberi pengaruh pada pemunculan karakter yang akan juga memunculkan gender dalam tokoh-tokoh utama pada cerita rakyat.

\section{KESIMPULAN}

Dari uraian analisa data dapat disimpulkan bahwa:

1. Tidak ada dominasi salah satu gender dalam cerita rakyat Tapanuli Tengah dalam Buku Bunga Rampai Cerita Rakyat Tapanuli Tengah (The Anthology of Central Tapanuli Folktales).

Cerita rakyat dalam buku tersebut terdapat 5 gender perempuan dan 5 gender laki-laki.

2. Gender perempuan muncul dalam cerita sebagai tokoh putri raja dan istri tokoh utama.

3. Penokohan dan gender tersebut muncul karena adanya unsur: (1) letak geografi Tapanuli Tengah adalah laut; (2) sistem pemerintahan kerajaan; (3) faktor agama Islam.

Dari kesimpulan di atas diharapkan akan dapat memberikan informasi kepada pembaca cerita rakyat tentang kehidupan sosial budaya masyarakat di Tapanuli Tengah. Dan diharapkan juga akan ada penelitian kesusasteraan lainnya yang mencoba meneliti topik seperti: bias gender, peranan cerita rakyat dalam pembelajaran, fungsi sosial cerita rakyat, pemertahanan cerita rakyat, dan lain-lain agar budaya nusantara seperti cerita rakyat dapat dilestarikan.

\section{DAFTAR PUSTAKA}

Atmazaki. 2007. Ilmu Sastra: Teori dan Terapan. Padang: UNP Press.

Bainar, Hj. (editor). 1998. Wacana Perempuan dalam Keindonesiaan dan Kemodernan. Yogyakarta:PT Pustaka CIDESINDO.

Danandjaja, James. 2007. Folklor Indonesia, Ilmu Gosip, Dongeng, dan lain-lain. Jakarta: Pustaka Utama Grafiti.

Hutomo, Suripan Sadi. 1991. Mutiara yang Hilang: Pengantar Studi Sastra Lisan. Surabaya. HISKI Jawa Timur.

Kutha Ratna, Nyoman. 2007. Teori, Metode, dan Teknik penelitian Sastra. Yogyakarta: Pustaka Pelajar.

Nasution, Edi Muhammad Yunus. 2007. Tulila: Muzik Bujukan Mandailing. Areca Books 120 Armenian Street, 10200 Penang, Malaysia).

Nurgiyantoro, Burhan. 2009. Teori Pengkajian Fiksi. Yogyakarta: Gajah Mada University Press.

Propp, V. 1987. Morfologi Cerita Rakyat (terjemahan Noriah Taslim). Kuala Lumpur: Dewan Bahasa Pustaka.

Rosidi, Ajip. 1995. Sastera dan Budaya: Kedaerahan dalam Keindonesiaan. Jakarta. Dunia Pustaka Jaya.

Semi, Atar. 1984. Anatomi Sastra. Padang: Sridarma.

Sugihastuti dan Suharto. 2010. Kritik Sastra Feminis, Teori dan Aplikasinya. Yogyakarta: Pustaka Pelajar. 